\title{
Heating of external surfaces by means of heat pumps
}

\author{
Krzysztof Nowak $^{1, *}$ \\ ${ }^{1}$ Rzeszow University of Technology, al. Powstanców Warszawy 12, 35-959 Rzeszów
}

\begin{abstract}
In winter we are forced to eliminate or mitigate the disadvantages associated with the accumulation of snow and ice on sidewalks, steps, driveways, roofs, squares, sports fields. There are many ways to remove snow and ice from the considered surfaces, including chemical, mechanical or use of a heating installation. Mechanical or manual methods do not always allow to completely remove snow and ice, while chemicals often have a negative impact on the environment. The most effective is the use of an electric or liquid heating installation. The article presents the results of technical analysis for a maneuver area heating system for driving training lesson using a heat pump with a ground heat exchanger, as well as financial analysis of its application in the established conditions. The literature lacks information on this subject, so it was interesting to investigate whether the proposed installation is technically and economically feasible.
\end{abstract}

\section{Introduction}

In winter we are forced to eliminate or mitigate the disadvantages associated with the accumulation of snow and ice on sidewalks, steps, driveways, roofs, squares, sports fields. The problem is so serious that it can lead to both surface damage and pose a threat during its operation [1]. For example, in the case of exploiting a sports field in the winter season, it is important to ensure proper conditions for grass growing and reducing the risk of injury to players in the event of a fall $[2,3]$.

There are many ways to remove snow and ice from the considered surfaces, including chemical, mechanical or use of a heating installation. Mechanical or manual methods do not always allow to completely remove snow and ice, while chemicals often have a negative impact on the environment. The most effective is the use of a heating installation. Due to the type of energy carrier, there are two basic systems for heating external surfaces, i.e. electrical and liquid systems.

The first one uses heating elements made of a resistance wire. The other is a water heating system. Both solutions are extremely effective, durable and friendly to the natural environment and are aimed at accelerating the melting of snow, ice, drying the surface and maintaining a constant surface and ground temperature, regardless of external conditions. The choice of type of heating installation depends on the installer, and often economic factors

\footnotetext{
*Corresponding author: krzynow@prz.edu.pl
} 
determine it. This publication considers ways to heat the maneuvering square for driving training $[4,5]$.

\section{Description of possible heating solutions}

The heating system enables heating surfaces under many types of surfaces, including turf pitches, asphalt, concrete, pavement or natural stone. Depending on the purpose of the surface, the installation can be made on the whole surface or in strategic, e.g. most frequented places. In the case of heating driveways to the garage, the first option works in situations of frequent and intensive use, while for moderate, private use, it is sufficient to heat only a part of the surface, e.g. two belts, on which the car's wheels move. In the case of heating the maneuvering area for driving training, the installation should be made in such a way that designated stands for exam tasks are visible during all weather conditions, i.e. preferably under the whole surface of the square.

Installations of this type are designed to protect against ice formation and snow retention. In order for the system to be efficient, the control module should enable installation before precipitation or icing occurs. The power consumption and time needed for proper system operation may be too high if there are very low temperatures and heavy snowfall. In practice, users tend to return to traditional methods and remove snow from manually.

\subsection{Electric heating system}

In the electric heating systems, heating elements made of a resistance wire are used. Heating cables insulated against moisture should have high resistance to mechanical damage. They are powered by 240 or $400 \mathrm{~V}$ electricity. Variable resistance cables are used, which adapt heating power to external conditions or longer-term and faster heating of solid-state cables. Instead of heating cables, heating mats can also be used [5].

The operation of the heating system is based on an automation system equipped with a number of sensors that measure the temperature of air, soil, heating cable and the humidity of the heated surface. The whole is connected to the power supply and control station. It is a convenient, relatively easy assembly [4].

The heating power of the system depends on from individual needs, climatic conditions, location and type of heated surface. Generally, it can be adopted for the climatic conditions that prevail in Poland, the installed power of the heated area should be in the range from 200 to $400 \mathrm{~W} / \mathrm{m}^{2}[6]$.

\subsection{Liquid heating system}

In liquid heating systems, heat pipes filled with a non-freezing liquid, e.g. a mixture of water and glycol, are used. Heating pipes are laid in loose layers, eg sand mixed with concrete, or compacted soil on which paving stones or asphalt are laid. The thickness of all layers above the pipe should not exceed $25 \mathrm{~cm}$ in the case of covering the pipe with soil, or $10 \mathrm{~cm}$ in the case of using a sand layer. If the pipes are laid in a concrete mortar, a thickness of $6 \mathrm{~cm}$ is recommended, finished with stone slabs. Figure 1 shows the crosssection of the surface heating system made of paving stones [16]. 


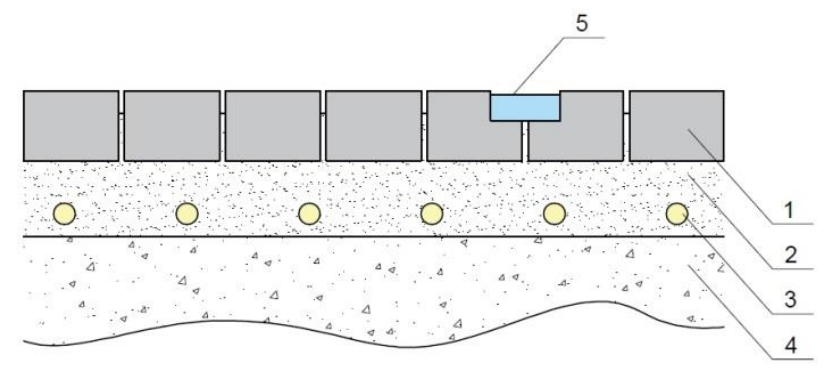

Fig. 1. The cross-section of the heating system surfaces made of paving stones: 1 - surface layer, 2 - sand and cement ballast, 3 - heating pipe, 4 - hardened ground, 5 - temperature and moisture sensor.

In any liquid system, the circulating pump forces the heating medium to flow. The installation creates a closed system with a properly selected source of heat. As in the case of an electrical system, the proper operation of the installation is the responsibility of the automation system equipped with sensors measuring the temperature of air, soil and heating medium. On the basis of the data from the sensors, the control system selects the appropriate parameters of the circulation pump and mixing system, so as to ensure the set conditions on the heated surface. Systems for heating external surfaces do not require high working temperature, so an interesting solution is to use a heat pump as a heat source. The source of heat can be heat from the ground, water or air. The use of a heat pump with a ground heat exchanger is characterized by high efficiency and allows to significantly reduce the operating costs of the heating installation $[7,8,9]$.

\section{Description of the heating system for maneuvering area for driving lessons}

The rest of this publication presents the method of heating the maneuvering square for training driving with the use of a liquid heating system. The source of heat is a heat pump with a ground heat exchanger in moist loamy soil. Figure 2 shows a diagram of the installation of a heat pump with a ground heat exchanger below the ground frosting zone.

The heated area is $1500 \mathrm{~m}^{2}$. The heating installation consists of a heat pump, circulation pumps, check valves, filters, expansion vessels, safety valves and a heat exchanger, that transfers heat between the heat pump system and the heating pipe system. The installation will extract heat from the moist loamy soil with a horizontal exchanger. The efficiency of heat transfer from the ground is assumed at the level of $\mathrm{q}_{\mathrm{e}}=30 \mathrm{~W} / \mathrm{m}^{2}$. The heat will be transferred to heating pipes arranged in the Tichelmann system. On the basis of literature information, the unit power of the heating installation $\left(Q_{j}\right)$ at the level of $200 \mathrm{~W} / \mathrm{m}^{2}$ was assumed. The heat flow supplied to the heating loops is calculated from the formula [7]:

$$
Q=Q_{j} \cdot A, \quad k W
$$

explanation:

$\mathrm{Q}_{\mathrm{j}}$ - unit power of the heating installation, $\mathrm{W} / \mathrm{m}^{2}$;

A - heated area, $\mathrm{m}^{2}$. 


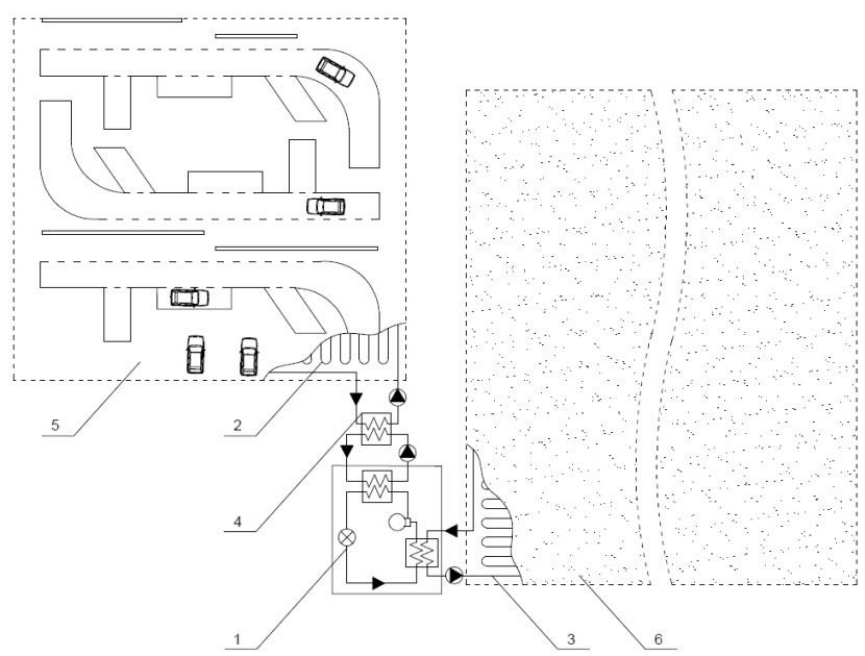

Fig. 2. Heat pump system diagram with ground heat exchanger: 1 - heat pump, 2 - heating system, 3 - heat source, 4 - heat exchanger, 5 - heated part of driving yard for driving lessons, 6 - ground heat exchanger surface.

Based on the calculation data for the analyzed solution and technical data available in the manufacturers' catalogs, an exemplary heat pump with a heating power of $305 \mathrm{~kW}$ was selected [10]. The amount of heat to be taken from the ground is calculated from the formula [7]:

explanation:

$$
Q_{k}=\frac{Q_{P C} \cdot(C O P-1)}{C O P}, \quad k W
$$

QPC - heating power of the heat pump, $\mathrm{kW}$;

COP - coefficient of performance, - .

Heat exchangers are designed as horizontal with parallel tube routing. The surface of the ground heat exchanger was calculated from the formula $[7,11]$ :

$$
F=\frac{Q_{k}}{q_{e}}, \quad m^{2}
$$

Table 1 presents the calculation data and parameters of the proposed heat pump. The annual coefficient of effectiveness (SCOP) was determined based on the guidelines for designing, making and receiving installations with heat pumps [17].

Table 1. Summary of computational data for the analysed solution.

\begin{tabular}{|c|c|}
\hline Heated area $A, \mathrm{~m}^{2}$ & 1500 \\
\hline $\begin{array}{c}\text { Efficiency of heat absorption from the ground } \mathrm{q}_{\mathrm{e}}, \\
\mathrm{W} / \mathrm{m}^{2}\end{array}$ & 30.00 \\
\hline Unit power of the heating installation $Q_{j}, \mathrm{~W} / \mathrm{m}^{2}$ & 200.00 \\
\hline The heat flow applied to heating loops $Q, \mathrm{~kW}$ & 300 \\
\hline Selected heat pump & Viessmann Vitocal 300G PRO 302.C230 \\
\hline Working point $\mathrm{B} / \mathrm{B},{ }^{\circ} \mathrm{C} /{ }^{\circ} \mathrm{C}$ & $3 / 10$ \\
\hline Heat output $\mathrm{QPC}, \mathrm{kW}$ & 305 \\
\hline Power consumption $\mathrm{P}, \mathrm{kW}$ & 35.9 \\
\hline Coefficient of Performance $\mathrm{COP},-$ & 8.5 \\
\hline Seasonal Coefficient of Performance $\mathrm{SCOP},-$ & 3.9 \\
\hline $\begin{array}{c}\text { The amount of heat to be taken from the ground } \mathrm{Q}_{\mathrm{k}}, \\
\mathrm{kW}\end{array}$ & 269 \\
\hline Surface of the ground heat exchanger $\mathrm{F}, \mathrm{m}^{2}$ & 8266 \\
\hline
\end{tabular}




\section{Evaluation of the economic efficiency of the installation}

The assessment of economic efficiency for the analyzed solution was carried [12]. Table 2 sets the investment cost of the entire installation. According to the information available in the literature and obtained from contractors, it was assumed that the cost of the lower and upper heat sources is about $35 \%$ of all costs, while the cost of the remaining components of the installation is around 20\% [12-15]. Calculations of the economic efficiency assessment were made for the time of using the installation from 400 hours to 1400 hours. One of the final result of the efficiency assessment was the calculation of the heat production costs by means of a heat pump in fixed conditions in relation to heat production costs only with using electric energy in newly designed installations assuming identical heating power (ie $305 \mathrm{~kW}$ ) and operating time of the installation (ie 400 hours to 1400 hours).

Table 2. Capital expenditures for the heating installation.

\begin{tabular}{|c|c|}
\hline Heat pump & 252000 PLN \\
\hline Lower and upper heat source & 196000 PLN \\
\hline $\begin{array}{c}\text { Other elements of the installation: heat exchanger, } \\
\text { pipelines, fittings, automation system, labor and } \\
\text { commissioning of the installation }\end{array}$ & 112000 PLN \\
\hline Total capital expenditure $\left(\mathrm{K}_{\text {inpc }}\right)$ & 560000 PLN \\
\hline
\end{tabular}

The amount of usable heat delivered during the year by the heat pump was calculated from the formula [12]:

explanation:

$$
Q_{a P C}=Q_{P C} \cdot T_{P C}, \quad k W h / \text { year }
$$

$\mathrm{T}_{\mathrm{PC}-}$ time of using the installed heat pump's power, $\mathrm{h}$.

The annual electricity consumption to generate useful heat by the heat pump [12]:

$$
K_{a P C}=\frac{Q_{a P C}}{S C O P}, \quad k W h / \text { year }
$$

The annual cost of producing useful heat by the heat pump [12]:

explanation:

$$
K_{a \text { el }}=K_{a P C} \cdot c_{e l}, \quad P L N / \text { year }
$$

$\mathrm{cel}_{\mathrm{el}}$ - the price of electricity, PLN/kWh.

The unit cost of generated heat was calculated from the formula [12]:

$$
q_{P C}=\frac{K_{a e l}}{Q_{a P C}}, \quad P L N / k W h
$$

Reducing the cost of obtaining heat per $1 \mathrm{kWh}$ in relation to electricity costs was calculated from the formula [12]:

$$
O=c_{e l}-q_{P C}, \quad P L N / k W h
$$

Savings obtained as a result of operating the installation during the year was calculated from the formula [12]:

$$
\Delta K=O \cdot Q_{a P C}, \quad P L N / \text { year }
$$

The payback period for outlays incurred for the implementation of the investment was calculated from the formula [12]:

$$
S P B T=\frac{K_{\text {inpc }}}{\Delta K}, \quad \text { year }
$$


To assess the effectiveness of the project NPV method was used, at a constant discount rate.

NPV was calculated from the formula [18]:

explanation:

$$
N P V=\sum_{t=1}^{N} \frac{\Delta K}{(1+p)^{t}}-\sum_{t=0}^{N} \frac{K_{a \text { el }}}{(1+p)^{t}}, \quad P L N
$$

$\mathrm{N}$ - system operation time, -;

$\mathrm{t}-$ year number, -;

$\mathrm{p}$ - discount rate, $\%$.

For example, in table 3 presents the initial data and calculation data of the economic effectiveness assessment for the analyzed solution when the time of using the installation is 900 hours.

Table 3. Initial data and calculation data of the economic effectiveness assessment the analysed solution when the time of using the installation is 900 hours. annual heat producing cost

\begin{tabular}{|c|c|}
\hline Time of using the installed heat pump power TPC, $\mathrm{h}$ & 900 \\
\hline System operation time N, years & 20 \\
\hline Amount of useful heat Qa PC, $\mathrm{kWh} /$ year & 274500 \\
\hline Discount rate $\mathrm{p}, \%$ & 8 \\
\hline Price of electricity cel, PLN/kWh & 0.59 \\
\hline Annual electricity consumption $K_{a}$ PC, $\mathrm{kWh} / \mathrm{year}$ & 70385 \\
\hline Annual heat producing cost $K_{a}$ el, PLN/year & 41527 \\
\hline The unit cost of heat generated qPC, PLN/kWh & 0.15 \\
\hline Reducing the cost of obtaining heat O, PLN/kWh & 0.44 \\
\hline Obtained savings $\triangle \mathrm{K}, \mathrm{PLN} / \mathrm{year}$ & 120428 \\
\hline Payback period SPBT, year & 4.65 \\
\hline Net present value NPV, PLN & 214663 \\
\hline
\end{tabular}

Figure 3 shows the graph of net present value (NPV) and the period of return on investment (SPBT) as a function of the installation's working time of 400 to 1400 hours.

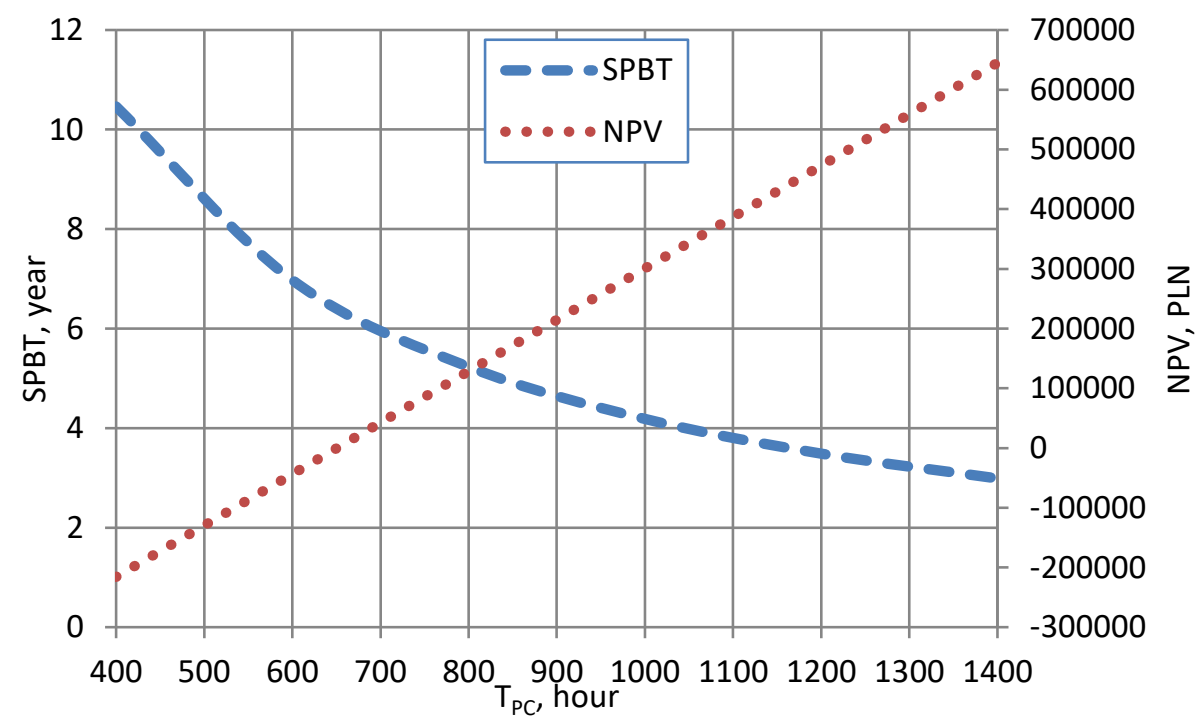

Fig. 3. The graph of obtained savings and a payback period for the installation's working time from 400 to 1400 hours. 


\section{Conclusions}

This publication presents the results of technical analysis for a manoeuvre area heating system for driving training using a heat pump with a ground heat exchanger, as well as economic analysis of its application in the established conditions. The literature lacks information on this subject, so it was interesting to investigate whether the proposed installation is technically and economically feasible.

A $305 \mathrm{~kW}$ heat pump was selected. It was assumed that the installation will work for 20 years. Calculations of the economic efficiency assessment were made for the time of use the installation during the heating season from 400 hours to 1400 hours. The final result of the efficiency assessment was the calculation of the reduction of the heat production costs by means of a heat pump in the set conditions in relation to the costs of generating heat exclusively from electricity energy in newly design installations. Calculated installation payback time (SPBT) and net present value (NPV). Based on the calculations made, it can be stated that heating the surface of the maneuvering area for driving lessons using a heat pump is technically possible and can be profitable. In each of the analyzed examples, the installation's payback time (SPBT) is shorter than the operating time. Based on the NPV, it can be seen that over a 20-year lifetime, the installation is profitable when is used more than $660 \mathrm{~h}\left(\mathrm{~T}_{\mathrm{PC}}\right)$ during each heating season. The installation's payback time in this case is 6.4 years. With the increase the installation operation time is reduced payback time and increases NPV.

Based on the analysis, it can be stated installations with a heat pump can be used in particular in places where there are significant rain or snow, and temperatures stay below $0^{\circ} \mathrm{C}$. The use of the external surface heating system allows to keep the surface without ice and snow, and thus allows safe and comfortable use. This is particularly important in the case of surfaces with a significant slope, where adverse weather conditions may make it difficult or impossible to move.

\section{References}

1. I. Piegdoń, B. Tchórzewska-Cieślak, D. Szpak, Environmental Engineering V (2017)

2. A. Trofimowicz, JCEA, 62 (2015)

3. G. Onyszczuk, A. Siuta-Olcha, Polska Inżynieria Środowiska pięć lat po wstąpieniu do Unii Europejskiej, 3 (Monografie Komitetu Inżynierii Środowiska PAN, 60, 2009)

4. http://naszmajster.pl/podgrzewany-podjazd-a123.html (29.01.2018)

5. J. Strzyżewski, Grzejnictwo elektryczne (Polcen, Warszawa, 2012)

6. Systemy ochrony przeciwoblodzeniowej, www.ensto.com (29.01.2018)

7. V. Pisarev, Projektowanie instalacji grzewczych z pompami ciepła (Oficyna Wydawnicza Politechniki Rzeszowskiej, Rzeszów, 2013)

8. W. Oszczak, Ogrzewanie domów z zastosowaniem pomp ciepła (WKŁ, Warszawa, 2009)

9. V. Pisarev, S. Rabczak, K. Nowak, Journal of Ecological Engineering 17 (2016)

10. Viessmann Products, http://viessmann.pl (29.01.2018)

11. P. Kopeć, JCEA, 62 (2015)

12. Z. Kusto, Uwarunkowania ekonomicznej efektywności pomp ciepła (IMP PAN, Gdańsk, 2006)

13. V. Pisarev, K. Nowak, Zeszyty Naukowe Politechniki Rzeszowskiej. Budownictwo i Inżynieria Środowiska, 59 (2012) 
14. V. Pisarev, K. Nowak, Zeszyty Naukowe Politechniki Rzeszowskiej. Budownictwo i Inżynieria Środowiska, 59 (2012)

15. http://jakbudowac.pl/Pompa-ciepla-ile-to-kosztuje (29.01.2018)

16. K. Sękowski, J. Juchnicki, System KAN-therm ogrzewanie powierzchni otwartych (Warszawa, 2004)

17. Wytyczne projektowania, wykonania i odbioru instalacji z pompami ciepła, PORT PC, (2014)

18. R. Stachniewicz, Civil and Environmental Engineering, 3 (2012) 